PARABLES FOR THE VIRTUAL 
POST-CONTEMPORARY INTERVENTIONS

Series Editors: Stanley Fish and Fredric Fameson 
Brian Massumi

\section{PARABLES FOR THE VIRTUAL}

Movement,

Affect,

Sensation 
(C) 2002 Duke University Press

All rights reserved

Printed in the United States of America

on acid-free paper $\infty$

Designed by C. H. Westmoreland

Typeset in Plantin Light with Frutiger display

by Keystone Typesetting, Inc.

Library of Congress Cataloging-

in-Publication Data

Massumi, Brian

Parables for the virtual: movement, affect,

sensation / Brian Massumi.

p. cm.-(Post-contemporary interventions)

Includes bibliographical references and index.

ISBN 0-8223-2882-8 (cloth : alk. paper)-

ISBN 0-8223-2897-6 (pbk. : alk. paper)

I. Movement (Philosophy) 2. Senses and

sensation. 3. Affect (Psychology)

I. Title. II. Series.

B I05.M65 M37 2002

I $28 / .62 \mathrm{I} \quad 200 \mathrm{IO} 582 \mathrm{II}$

2nd printing, 2003 